\title{
Biofortification of maize fodder with zinc improves forage productivity and nutritive value for livestock
}

\author{
B. Kumar ${ }^{1,3}$ and H. Ram ${ }^{2}$ \\ ${ }^{1}$ Guru Angad Dev Veterinary and Animal Sciences University, Ludhiana, Punjab, India \\ ${ }^{2}$ Punjab Agricultural University, Ludhiana, Punjab, India
}

KEY WORDS: biofortification, digestibility parameters, forage quality, forage yield, maize fodder, zinc

Received: 28 December 2020

Revised: $\quad 3$ March 2021

Accepted: $\quad 20$ April 2021

${ }^{3}$ Corresponding author:

e-mail: dr.balwinderkumar@rediffmail.com

\begin{abstract}
Zinc $(\mathrm{Zn})$ deficiency in the soil negatively affects production of maize forage, and consequently dietary $\mathrm{Zn}$ intake by the livestock. The aim of the study was to investigate the effect of rate and method of $\mathrm{ZnSO}_{4} \cdot \mathrm{H}_{2} \mathrm{O}$ application on forage yield, quality and digestibility of maize fodder grown on a low DTPA-extractable $\mathrm{Zn}$ soil. The treatments were: $\mathrm{T}_{1}=$ control; $\mathrm{T}_{2}=$ foliar application of $0.3 \% \mathrm{ZnSO}_{4} \cdot \mathrm{H}_{2} \mathrm{O} 30$ days after sowing (DAS); $\mathrm{T}_{3}^{2}=$ foliar application of $0.3 \% \mathrm{ZnSO}_{4} \cdot \mathrm{H}_{2} \mathrm{O} 30$ and $40 \mathrm{DAS} ; \mathrm{T}_{4}=$ soil application of $16 \mathrm{~kg} / \mathrm{ha} \mathrm{ZnSO} \mathrm{Zn}_{4} \cdot \mathrm{H}_{2} \mathrm{O} ; \mathrm{T}_{5}=$ soil application of $16 \mathrm{~kg} / \mathrm{ha} \mathrm{ZnSO} \cdot \cdot \mathrm{H}_{2} \mathrm{O}+\mathrm{T}_{2}$; and $\mathrm{T}_{6}=$ soil application of $16 \mathrm{~kg} / \mathrm{ha} \mathrm{ZnSO}_{4} \cdot \mathrm{H}_{2} \mathrm{O}+\mathrm{T}_{3}$. The experiment was performed in a randomized complete block design. The optimal rate and method of $\mathrm{ZnSO}_{4} \cdot \mathrm{H}_{2} \mathrm{O}$ application resulting in improved fodder yield and quality of maize was obtained by $T_{6}$ treatment. An increase in the fresh fodder yield, dry matter (DM) yield and $\mathrm{Zn}$ uptake by 25 , 46.9 and $160.7 \%$, respectively were recorded under $T_{6}$ treatment. Digestibility parameters as digestible crude protein, total digestible nutrients, digestible DM, DM intake, net energy for lactation, digestible feed energy, relative feed value and relative forage quality of fodder were significantly $(P \leq 0.05)$ improved by soil plus double foliar $\mathrm{ZnSO}_{4} \cdot \mathrm{H}_{2} \mathrm{O}$ fertilization $\left(\mathrm{T}_{6}\right)$; however, a significant reduction in fibres content in fodder was noted. So, the $\mathrm{Zn}$ enrichment method combining soil addition and foliar spraying is the best one to improve the quality of maize fodder, and thus can be a good way to introduce $\mathrm{Zn}$ into animal nutrition.
\end{abstract}

\section{Introduction}

Maize (Zea mays L.) is an important cereal crop worldwide, used as food for human beings, feed for livestock, and a raw material for industry (Anees et al., 2016). It is more commonly used in lifestock feeding than other cereal fodder crops due to its higher digestibility and palatability (Wadhwa et al., 2010). Farmers also prefer maize for making high-quality maize-cob silage for feeding the livestock during lean fodder production periods (Kumar et al., 2019).
Zinc ( $\mathrm{Zn})$ deficiency in the soil is one of the major micronutrient constraints to crop and pasture production throughout the world in all regions with arid to tropical climate (Alloway, 2008; Cakmak and Kutman, 2018). The major reason for the deficiency of micronutrients, such as $\mathrm{Zn}$, is chiefly ascribed to the introduction of high yielding crop varieties in the past, imbalanced fertilizer application to the soil and low soil organic matter content (Gupta et al., 2016; Kumar et al., 2016; Pal et al., 2020). More than $50 \%$ of the Indian soils are now deficient in $\mathrm{Zn}$, particularly in highly intensive cultivated 
Indo-Gangetic plains of North-West India (Gupta et al., 2016; Cakmak and Kutman, 2018). The deficiency of $\mathrm{Zn}$ in Indian soils is expected to increase to $63 \%$ by the year 2025 as more areas of marginal land are brought under intensive cultivation without adequate micronutrient fertilization (Tripathi et al., 2009). Moreover, soil $\mathrm{pH}$, redox conditions, cation exchange capacity (CEC), microbial activity, organic matter and water content are important soil properties governing soil mineral availability to the plants. High soil $\mathrm{pH}$ is often considered as the major factor limiting the phyto-availability of $\mathrm{Zn}$ and other micronutrients in the rhizosphere solution (Gupta et al., 2016). The soils of the region are $\mathrm{Zn}$-deficient as the critical level of $\mathrm{Zn}$ deficiency in soils falls in the range from 0.6 to $1.0 \mathrm{mg} \mathrm{Zn} / \mathrm{kg}$ (diethylenetriaminepentaacetic acid (DTPA)-extractable). The low level of $\mathrm{Zn}$ in soils has resulted in a widespread deficiency of this element in both food and forage crops (Alloway, 2008; Gupta et al., 2016); thereby adversely affecting the health of the human and livestock in tropical countries (Tripathi et al., 2009; Kumar and Dhaliwal, 2021). Moreover, forage crops are generally grown in marginal soils which are deficient in micronutrient contents, particularly in Zn in South Asian countries leading to low yield and quality of fodder for the livestock (Alloway, 2008; Kumar et al., 2016). In a study conducted by Yadav and Khirwar (2000) in Haryana, India, it was reported a positive correlation between low levels of $\mathrm{Zn}$ in buffalo milk and low level of $\mathrm{Zn}$ in soil and fodder grown on it. Zinc deficiency in adult animals can cause lameness, hoof deformation, impaired locomotion, increased risk of infectious diseases, lower or impaired reproductive efficiency, anoestrus and repeat breeding leading to low milk production (Hosnedlova et al., 2007). A significant increase in $\mathrm{Zn}$ content in milk can be achieved by biofortification of forage crop which might further meet the $\mathrm{Zn}$ requirements of human beings through milk as well (Hosnedlova et al., 2007).

Maize is reported to be highly responsive to the soil as well as the foliar application of $\mathrm{Zn}$ (Alloway, 2008; Ahmad et al., 2012; Ryan et al., 2013). The critical level of $\mathrm{Zn}$ in crops (maize, wheat, cowpea etc.) falls in the range of $10-20 \mathrm{mg} / \mathrm{kg}$ on a dry matter basis (Kumar and Dhaliwal, 2021). Significant reduction in fodder yield and quality of maize has been reported due to $\mathrm{Zn}$ deficiency in soil (Ahmad et al., 2012). There is a strong need for enriching the maize forage with $\mathrm{Zn}$ through soil or foliar application which is economical and farmer-friendly.
Till now, Zn biofortification of cereals and legumes have been reported at many parts of the world (Alloway, 2008); however, a little information is available in the literature regarding the $\mathrm{Zn}$ biofortification of forage crops (Capstaff and Miller, 2018) and its effect on digestibility parameters of the forage. The economic importance of livestock production offers the opportunity to biofortify forage crops, thereby, improving the health of animals and, consequently their product consumers (Capstaff and Miller, 2018). The increased $\mathrm{Zn}$ uptake by the crop under $\mathrm{Zn}$ fertilization will help to meet the $\mathrm{Zn}$ requirements of livestock, particularly in South Asian countries where soils and forage crops are generally deficient in Zn (Alloway, 2008; Ryan et al., 2013; Cakmak and Kutman, 2018). Maize fodder enriched with $\mathrm{Zn}$ when fed to the livestock will increase milk production, increase $\mathrm{Zn}$ content in milk and reduce the risk of infectious diseases such as metritis and mastitis in the cattle (Hosnedlova et al., 2007; Gupta et al., 2016; Kumar et al., 2016). The present field study was, therefore, planned to assess the effect of soil and foliar-applied $\mathrm{Zn}$ on productivity and quality of maize fodder in a semi-arid environment of the Indo-Gangetic plains of North-West India. It was hypothesized that $\mathrm{Zn}$ biofortification through the soil and/or foliar application will increase maize herbage yield, quality and digestibility of fodder for livestock nutrition.

\section{Material and methods}

\section{Study site, weather and soil characteristics}

The field experiment was conducted for two consecutive years during the summer seasons of 2013 (July to September) and 2014 (May to July) at the Fodder Production Area, Guru Angad Dev Veterinary and Animal Sciences University, Ludhiana, Punjab, India $\left(30^{\circ} 56^{\prime} \mathrm{N}, 75^{\circ} 52^{\prime} \mathrm{E}, 247 \mathrm{~m}\right.$ above mean sea level). The total amount of rainfall during the cropping seasons was 375.6 and $44.0 \mathrm{~mm}$ during 2013 and 2014, respectively. Maximum and minimum air temperatures were 33.5 and $25.8^{\circ} \mathrm{C}$ during the 2013 growing season, and 38.4 and $25.4^{\circ} \mathrm{C}$ during the 2014 growing season. Mean relative air humidity ranged from 65.8 to $86.8 \%$ and from 36.4 to $61.2 \%$ for the 2013 and 2014 seasons, respectively. Lower sunshine hours were recorded for the 2013 growing season in comparison to that in 2014.

Soil texture, $\mathrm{pH}$ and conductivity (soil:water ratio of 1:2), organic carbon, available $\mathrm{N}$, available (Olsen) $\mathrm{P}, 1 \mathrm{~N} \mathrm{NH} \mathrm{NH}_{4} \mathrm{OAc}$-extractable $\mathrm{K}$, available 
micronutrients (DTPA-extractable $\mathrm{Zn}, \mathrm{Fe}, \mathrm{Cu}$ and $\mathrm{Mn})$ contents were measured on the atomic absorption spectrophotometer (Varian AAS FS 240; Varian, Palo Alto, CA, USA) by standard methods as described by Jackson (1973). The top $15 \mathrm{~cm}$ of the soil surface was loamy sand (TypicUstochrept) in texture, having $\mathrm{pH} 8.4$ and electrical conductivity (EC) $0.21 \mathrm{dSm}^{-1}$. The soil of the experimental field was low in organic C $(0.22 \%)$, low in available $\mathrm{N}$ (258 kg/ha), available P (11.9 kg/ha) and DTPAextractable $\mathrm{Zn}(0.52 \mathrm{mg} / \mathrm{kg})$ as measured by atomic absorption spectroscopy. The soil had moderate content of available K (Jackson, 1973).

\section{Experimental design and treatments}

The experiment was conducted with a set of six treatments in a randomized complete block design (RCBD) with three replications. The six treatments of $\mathrm{ZnSO}_{4} \cdot \mathrm{H}_{2} \mathrm{O}$ application were $\mathrm{T}_{1}=$ control, $\mathrm{T}_{2}=$ foliar spray of $\mathrm{ZnSO}_{4} \cdot \mathrm{H}_{2} \mathrm{O}(0.3 \%) 30$ days after sowing, $\mathrm{T}_{3}=$ two foliar sprays of $\mathrm{ZnSO}_{4} \cdot \mathrm{H}_{2} \mathrm{O}$ $(0.3 \%) 30$ and 40 days after sowing, $\mathrm{T}_{4}=$ soil application of $16 \mathrm{~kg} / \mathrm{ha} \mathrm{ZnSO}_{4} \cdot \mathrm{H}_{2} \mathrm{O}$ at sowing, $\mathrm{T}_{5}=$ soil application of $\mathrm{ZnSO}_{4} \cdot \mathrm{H}_{2} \mathrm{O}(16 \mathrm{~kg} / \mathrm{ha})$ at sowing plus foliar spray of $\mathrm{ZnSO}_{4} \cdot \mathrm{H}_{2} \mathrm{O}(0.3 \%)$ 30 days after sowing and $\mathrm{T}_{6}=$ soil application of $\mathrm{ZnSO}_{4} \cdot \mathrm{H}_{2} \mathrm{O}(16 \mathrm{~kg} / \mathrm{ha})$ at sowing plus foliar spray of $\mathrm{ZnSO}_{4} \cdot \mathrm{H}_{2} \mathrm{O}(0.3 \%) 30$ and 40 days after sowing. Zinc as $\mathrm{Zn}$ sulphate monohydrate $\left(\mathrm{ZnSO}_{4} \cdot \mathrm{H}_{2} \mathrm{O}\right)$ with $33 \% \mathrm{Zn}$ was used in the study. The soil $\mathrm{Zn}$ application treatment consisted of $16 \mathrm{~kg} \mathrm{ZnSO}_{4} \cdot \mathrm{H}_{2} \mathrm{O}$ per ha ( $5 \mathrm{~kg} \mathrm{Zn}$ per ha), which was dissolved in water (250 1/ha), then sprayed on the soil surface to ensure uniform distribution and was later incorporated into the soil before planting. In foliar application treatments, $0.75 \mathrm{~kg}$ $\mathrm{ZnSO}_{4} \cdot \mathrm{H}_{2} \mathrm{O}$ per ha $(0.25 \mathrm{~kg} \mathrm{Zn}$ per ha) and unslaked lime, were dissolved in 2501 water per ha, and the solution was sprayed on maize foliage 30 (V7 stage) and 40 (V10 stage) days after sowing during evening hours when the wind was calm and the temperature was mild. Applications of foliar sprays on the crop at different stages were made with a manually operated knapsack sprayer pump.

\section{Agronomic practices}

Maize cultivar J 1006 (Punjab Agricultural University, Ludhiana, India) was used in the study. Sowing was done on 19 July and 9 May during 2013 and 2014, respectively, using a seed rate at $50 \mathrm{~kg} / \mathrm{ha}$ with the spacing of $30 \times 10 \mathrm{~cm}$ (333333 plants/ha) in a plot size of $14.4 \mathrm{~m}^{2}$. The recommended dose $90 \mathrm{~kg} \mathrm{~N} /$ ha was applied as urea $(46 \% \mathrm{~N})$, split into two halves, one applied at sowing and the other applied as top dressing 30 days after sowing. In addition, $30 \mathrm{~kg} \mathrm{P}_{2} \mathrm{O}_{5}$ was applied at sowing as single super phosphate $\left(16.0 \% \mathrm{P}_{2} \mathrm{O}_{5}\right)$. For weed control, herbicide atrazine $50 \mathrm{WP}(1.25 \mathrm{~kg} / \mathrm{ha})$ was sprayed immediately after sowing. The crop was manually harvested from a net area measuring $9.9 \mathrm{~m}^{2}$ in the middle of each plot on 23 September 2013 and 14 July 2014 at the age of 60 days for green fodder purpose (Bhatti and Kaur, 2020). Fresh fodder yield was measured by harvesting the crop from an area of $9.9 \mathrm{~m}^{2}$ which was then converted to $\mathrm{Mg} / \mathrm{ha}$.

\section{Laboratory analyses}

Whole maize plants collected from each plot at harvest were washed sequentially with tap water, acidulated water containing $0.01 \mathrm{~N} \mathrm{HCl}$, distilled water and deionized water. Sub-samples were then airdried followed by oven drying at $60{ }^{\circ} \mathrm{C}$ to a constant weight. The dried samples were ground in a Wiley mill (Thomas Scientific, Swedesboro, NJ, USA) fitted with stainless steel blades and passed through a 40-mm mesh sieve and stored in airtight plastic bags for nutrient composition determination. Crude protein $(\mathrm{CP})$ content was (determined by multiplying $\mathrm{N} \%$ by 6.25 and expressed as a percentage (AOAC International, 2000). Zinc uptake was calculated by multiplying the $\mathrm{Zn}$ content (determined by an atomic absorption spectroscopy) by dry matter (DM) yield of fodder (Page et al., 1982).

\section{Estimation of fodder quality and digestibility parameters}

Acid detergent fibre (ADF) and neutral detergent fibre (NDF) were determined using the procedure given by Van Soest et al. (1991). Hemicellulose content was calculated by the difference between NDF and ADF. Total digestible nutrients (TDN), digestible dry matter (DDM), dry matter intake (DMI), digestible crude protein (DCP), net energy for lactation $\left(\mathrm{NE}_{\mathrm{L}}\right)$, digestible feed energy (DFE), relative feed value (RVF), relative forage quality (RFQ) were estimated according to the following equations adapted from Lithourgidis et al. (2006) and Kumar et al. (2016) from the measured variables:

$$
\begin{aligned}
& \text { total digestible nutrients }(\mathrm{TDN}, \%)= \\
& 87.84-(0.7 \times \mathrm{ADF})
\end{aligned}
$$

dry matter intake (DMI, \% DM basis $)=120 / \mathrm{NDF}$; dry matter digestibility $(\mathrm{DDM}, \%)=$ $88.9-(0.779 \times \mathrm{ADF})$;

digestible crude protein $(\mathrm{DCP}, \%)=$ $(0.929 \times \mathrm{CP})-3.77$; 
net energy for lactation $\left(\mathrm{NE}_{\mathrm{L}}, \mathrm{Mcal} / \mathrm{kg}\right)=$

$$
1.5-(\mathrm{ADF} \times 0.0267)
$$

digestible feed energy $(\mathrm{DFE}, \mathrm{Mcal} / \mathrm{kg})=$ $4.4 \times(\mathrm{TDN} / 100)$

relative feed value $(\mathrm{RFV}, \%)=$

$(\mathrm{DDM} \times \mathrm{DMI}) / 1.29$;

relative feed quality $(\mathrm{RFQ}, \%)=$

$(\mathrm{TDN} \times \mathrm{DMI}) / 1.23$.

\section{Statistical analyses}

The data were subjected to analysis of variance (ANOVA) using IRRISTAT version 92 (IRRI, 1992). Means comparisons were done using the least significant difference (LSD) procedure at $P \leq 0.05$. Pearson's correlation coefficient (r) was calculated among the different variables and a correlation matrix was prepared to quantify the relationship among the different variables and fodder yield and other traits.

\section{Results}

\section{Fresh fodder yield and dry matter yield}

Fresh fodder yield (FFY) of maize was significantly $(P \leq 0.05)$ affected by the $\mathrm{Zn}$ fertilization treatments (Table 1). In comparison to the control, all treatments of $\mathrm{Zn}$ sulphate application improved the FFY (Table 1). The highest FFY of $57 \mathrm{Mg} /$ ha was achieved with the application of $\mathrm{ZnSO}_{4} \cdot \mathrm{H}_{2} \mathrm{O}$ (16 kg/ha) at sowing combined with foliar application of $0.3 \% \mathrm{ZnSO}_{4} \cdot \mathrm{H}_{2} \mathrm{O} 30$ and 40 days after sowing $\left(\mathrm{T}_{6}\right)$, registering an increase of $25 \%$ over the control; however, $\mathrm{T}_{6}$ treatment did not differ significantly from the $\mathrm{T}_{5}$ treatment (soil application plus singular foliar spray). Zinc application to soil alone $\left(\mathrm{T}_{4}\right)$ was superior to singular foliar application of
$\mathrm{ZnSO}_{4} \cdot \mathrm{H}_{2} \mathrm{O}\left(\mathrm{T}_{2}\right)$ in enhancing the FFY; but there was no significant difference between $\mathrm{T}_{3}$ (double foliar sprays) and $\mathrm{T}_{4}$ (soil alone) treatments. Furthermore, no statistical difference in FFY between $T_{2}$ (singular foliar spray) and $\mathrm{T}_{3}$ (double foliar spray) treatments was noticed. The improvement in mean FFY amounted 9.8, 14.6 and $16.7 \%$ with the $\mathrm{T}_{2}, \mathrm{~T}_{3}$ and $\mathrm{T}_{4}$ treatments, respectively, over control.

Similar to FFY, the increasing trend in dry matter yield (DMY) was also recorded with $\mathrm{Zn}$ fertilization. Combined application of soil plus foliar $\mathrm{ZnSO}_{4} \cdot \mathrm{H}_{2} \mathrm{O}$ sprays 30 and 40 days after sowing $\left(\mathrm{T}_{6}\right)$ increased DMY to the highest level which accounted for $46.9 \%$ over control (Table 1), but no significant difference between $\mathrm{T}_{6}$ and $\mathrm{T}_{5}$ treatments (soil $\mathrm{Zn}$ application plus single foliar $\mathrm{Zn}$ ) was recorded. Sole foliar application of $\mathrm{ZnSO}_{4} \bullet \mathrm{H}_{2} \mathrm{O} 30$ days after sowing $\left(\mathrm{T}_{2}\right)$ increased DMY to the tune of $18.5 \%$ and was significantly superior to the control. The $\mathrm{T}_{2}$ and $\mathrm{T}_{3}$ treatments were statistically the same in respect to DMY, but both treatments were found better than the control treatment $\left(T_{1}\right)$. Similarly, the increase in DMY of the crop was also statistically similar in the $\mathrm{T}_{3}, \mathrm{~T}_{4}$ and $\mathrm{T}_{5}$ treatments (Table 1 ).

\section{Zinc uptake by fodder}

Zinc uptake $(\mathrm{ZnU})$ by maize fodder was significantly affected by the different $\mathrm{Zn}$ application treatments (Table 1). The soil $\mathrm{ZnSO}_{4} \cdot \mathrm{H}_{2} \mathrm{O}$ along with two foliar sprays of $0.3 \% \mathrm{ZnSO}_{4} \cdot \mathrm{H}_{2} \mathrm{O} 30$ and 40 days after sowing $\left(\mathrm{T}_{6}\right)$ recorded $423.7 \mathrm{~g} / \mathrm{ha}$ of Zn uptake in fodder which was significantly higher than the control $(160.7 \%)$ and other experimental treatments. Among all $\mathrm{Zn}$ fertilization treatments, the lowest increase in $\mathrm{ZnU}$ in fodder was recorded with the foliar spray of $0.3 \% \mathrm{ZnSO}_{4} \cdot \mathrm{H}_{2} \mathrm{O} 30$ days

Table 1. Effect of foliar and soil-applied zinc $(\mathrm{Zn})$ sulphate $\left(\mathrm{ZnSO}_{4} \cdot \mathrm{H}_{2} \mathrm{O}\right)$ on fresh fodder yield (FFY), dry matter yield (DMY) and $\mathrm{Zn}$ uptake ( $\left.\mathrm{ZnU}\right)$ by maize (mean of two years)

\begin{tabular}{cclclll}
\hline Indices & FFY, Mg/ha & $\begin{array}{l}\text { Percent increase } \\
\text { over control }\end{array}$ & DMY, Mg/ha & $\begin{array}{l}\text { Percent increase } \\
\text { over control }\end{array}$ & ZnU, g/ha & $\begin{array}{l}\text { Percent increase } \\
\text { over control }\end{array}$ \\
\hline $\begin{array}{l}\text { Treatment } \\
T_{1}\end{array}$ & $45.6 \pm 1.72^{\mathrm{d}}$ & - & $8.1 \pm 0.21^{\mathrm{d}}$ & - & $162.5 \pm 6.12^{\mathrm{e}}$ & - \\
$\mathrm{T}_{2}$ & $50.1 \pm 0.75^{\mathrm{c}}$ & 9.8 & $9.6 \pm 0.22^{\mathrm{c}}$ & 18.5 & $236.3 \pm 3.91^{\mathrm{d}}$ & 45.4 \\
$\mathrm{~T}_{3}$ & $52.3 \pm 0.30^{\mathrm{bc}}$ & 14.6 & $10.2 \pm 0.24^{\mathrm{bc}}$ & 25.9 & $281.3 \pm 3.53^{\mathrm{c}}$ & 73.1 \\
$\mathrm{~T}_{4}$ & $53.2 \pm 0.96^{\mathrm{b}}$ & 16.7 & $10.5 \pm 0.10^{\mathrm{b}}$ & 29.6 & $273.1 \pm 9.03^{\mathrm{c}}$ & 68.0 \\
$\mathrm{~T}_{5}$ & $55.6 \pm 1.87^{\mathrm{ab}}$ & 21.9 & $11.3 \pm 0.28^{\mathrm{ab}}$ & 39.5 & $364.2 \pm 9.04^{\mathrm{b}}$ & 124.1 \\
$\mathrm{~T}_{6}$ & $57.0 \pm 1.05^{\mathrm{a}}$ & 25.0 & $11.9 \pm 0.25^{\mathrm{a}}$ & 46.9 & $423.7 \pm 15.1^{\mathrm{a}}$ & 160.7 \\
$\mathrm{SEM}$ & 0.77 & - & 0.30 & - & 6.3 & - \\
LSD $(P \leq 0.05)$ & 2.5 & - & 0.8 & - & 20.0 & - \\
\hline
\end{tabular}

1 treatments: $\mathrm{T}_{1}=$ control, $\mathrm{T}_{2}=$ foliar spray of $\mathrm{ZnSO}_{4} \cdot \mathrm{H}_{2} \mathrm{O}(0.3 \%) 30$ days after sowing, $\mathrm{T}_{3}=$ two foliar sprays of $\mathrm{ZnSO}_{4} \cdot \mathrm{H}_{2} \mathrm{O}(0.3 \%) 30$ and 40 days after sowing, $\mathrm{T}_{4}=$ soil application of $16 \mathrm{~kg} / \mathrm{ha} \mathrm{ZnSO}{ }_{4} \cdot \mathrm{H}_{2} \mathrm{O}$ at sowing, $\mathrm{T}_{5}=$ soil application of $\mathrm{ZnSO}_{4} \cdot \mathrm{H}_{2} \mathrm{O}(16 \mathrm{~kg} / \mathrm{ha}$ ) at sowing plus foliar spray of $\mathrm{ZnSO}_{4} \cdot \mathrm{H}_{2} \mathrm{O}(0.3 \%) 30$ days after sowing, and $\mathrm{T}_{6}=$ soil application of $\mathrm{ZnSO}_{4} \cdot \mathrm{H}_{2} \mathrm{O}(16 \mathrm{~kg} / \mathrm{ha})$ at sowing plus foliar spray of $\mathrm{ZnSO}_{4} \cdot \mathrm{H}_{2} \mathrm{O}$ $(0.3 \%) 30$ and 40 days after sowing; SEM - standard error of the mean; LSD - least significant difference; ${ }^{\text {a-e }}$ - means within columns with different superscripts are significantly different at $P \leq 0.05$ 
after sowing $\left(\mathrm{T}_{2}\right)$, yet it was significantly superior to the control. Two foliar sprays of $0.3 \% \mathrm{ZnSO}_{4} \cdot \mathrm{H}_{2} \mathrm{O}$ 30 and 40 days after sowing caused significantly higher $\mathrm{ZnU}$ in fodder over $\mathrm{T}_{2}$ treatment. On the other hand, basal soil application of $16 \mathrm{~kg} / \mathrm{ha}$ $\mathrm{ZnSO}_{4} \cdot \mathrm{H}_{2} \mathrm{O}\left(\mathrm{T}_{4}\right)$ treatment recorded $22.6 \%$ more $\mathrm{ZnU}$ in fodder biomass than the sole foliar application of $0.3 \% \mathrm{ZnSO}_{4} \cdot \mathrm{H}_{2} \mathrm{O} 30$ days after sowing $\left(\mathrm{T}_{2}\right)$, but did not differ from the foliar application of $0.3 \%$ $\mathrm{ZnSO}_{4} \cdot \mathrm{H}_{2} \mathrm{O} 30$ and 40 days after sowing $\left(\mathrm{T}_{3}\right)$.

\section{Crude protein content}

Significant $(P \leq 0.05)$ improvement in forage crude protein $(\mathrm{CP})$ content was recorded with the soil, foliar and soil plus foliar application of Zn (Table 2).
Foliar $\mathrm{ZnSO}_{4} \cdot \mathrm{H}_{2} \mathrm{O}$ application treatments $\left(\mathrm{T}_{2}\right.$ and $\mathrm{T}_{3}$ ) were found statistically similar in respect to NDF and ADF, but were significantly superior over control. Soil application of $\mathrm{ZnSO}_{4} \cdot \mathrm{H}_{2} \mathrm{O}\left(\mathrm{T}_{4}\right)$ caused significantly lower NDF values than foliar treatments $\left(\mathrm{T}_{2}\right.$ and $\left.\mathrm{T}_{3}\right)$; however, in the case of ADF the $\mathrm{T}_{4}$ and $\mathrm{T}_{3}$ treatments did not differ significantly between each other (Table 2).

\section{Estimated digestibility parameters}

Means of TDN of the forage were improved by $2.5 \%$ with the $\mathrm{T}_{6}$ treatment over the control (Table 2 ). Singular foliar application treatment of $\mathrm{ZnSO}_{4} \cdot \mathrm{H}_{2} \mathrm{O}$ $\left(\mathrm{T}_{2}\right)$ was significantly better in improving TDN of fodder by $0.8 \%$ over the control treatment, but

Table 2. Effect of zinc $(\mathrm{Zn})$ sulphate $\left(\mathrm{ZnSO}_{4} \cdot \mathrm{H}_{2} \mathrm{O}\right)$ application on the crude protein (CP) content, neutral detergent fibre (NDF), acid detergent fibre (ADF), total digestible nutrients (TDN) and hemi-cellulose (HC) content of maize fodder (mean of two years), \% dry matter

\begin{tabular}{|c|c|c|c|c|c|}
\hline Indices & $\mathrm{CP}$ & NDF & ADF & TDN & $\mathrm{HC}$ \\
\hline \multicolumn{6}{|l|}{ Treatments $^{1}$} \\
\hline $\mathrm{T}_{1}$ & $8.13 \pm 0.12^{d}$ & $66.8 \pm 0.14^{\mathrm{a}}$ & $36.6 \pm 0.18^{a}$ & $62.2 \pm 0.12^{\mathrm{d}}$ & $30.3 \pm 0.07^{a}$ \\
\hline $\mathrm{T}_{2}$ & $8.78 \pm 0.42^{c}$ & $65.8 \pm 0.07^{b}$ & $35.9 \pm 0.03^{b}$ & $62.7 \pm 0.03^{c}$ & $29.9 \pm 0.09^{a}$ \\
\hline $\mathrm{T}_{3}$ & $9.02 \pm 0.30^{b}$ & $65.7 \pm 0.16^{b}$ & $35.5 \pm 0.12^{\mathrm{bc}}$ & $63.1 \pm 0.10^{b}$ & $30.2 \pm 0.27^{\mathrm{a}}$ \\
\hline $\mathrm{T}_{4}$ & $9.23 \pm 0.29^{a b}$ & $64.6 \pm 0.12^{c}$ & $35.4 \pm 0.25^{c}$ & $63.0 \pm 0.17^{b c}$ & $29.2 \pm 0.19^{b}$ \\
\hline $\mathrm{T}_{5}$ & $9.51 \pm 0.18^{\mathrm{ab}}$ & $63.8 \pm 0.17^{d}$ & $35.2 \pm 0.26^{c}$ & $63.2 \pm 0.17^{b}$ & $28.6 \pm 0.21^{c}$ \\
\hline $\mathrm{T}_{6}$ & $9.76 \pm 0.02^{\mathrm{a}}$ & $63.2 \pm 0.13^{e}$ & $34.3 \pm 0.07^{d}$ & $63.8 \pm 0.06^{a}$ & $28.8 \pm 0.20^{\mathrm{bc}}$ \\
\hline SEM & 0.23 & 0.30 & 0.18 & 0.09 & 0.17 \\
\hline $\operatorname{LSD}(P \leq 0.05)$ & 0.72 & 0.50 & 0.50 & 0.30 & 0.50 \\
\hline
\end{tabular}

${ }^{1}$ treatments: $\mathrm{T}_{1}=$ control, $\mathrm{T}_{2}=$ foliar spray of $\mathrm{ZnSO}_{4} \cdot \mathrm{H}_{2} \mathrm{O}(0.3 \%) 30$ days after sowing, $\mathrm{T}_{3}=$ two foliar sprays of $\mathrm{ZnSO}_{4} \cdot \mathrm{H}_{2} \mathrm{O}(0.3 \%) 30$ and 40 days after sowing, $\mathrm{T}_{4}$ = soil application of $16 \mathrm{~kg} / \mathrm{ha} \mathrm{ZnSO}_{4} \cdot \mathrm{H}_{2} \mathrm{O}$ at sowing, $\mathrm{T}_{5}$ = soil application of $\mathrm{ZnSO}_{4} \cdot \mathrm{H}_{2} \mathrm{O}(16 \mathrm{~kg} / \mathrm{ha})$ at sowing plus foliar spray of $\mathrm{ZnSO}_{4} \cdot \mathrm{H}_{2} \mathrm{O}(0.3 \%) 30$ days after sowing, and $\mathrm{T}_{6}^{2}=$ soil application of $\mathrm{ZnSO}_{4} \cdot \mathrm{H}_{2} \mathrm{O}(16 \mathrm{~kg} / \mathrm{ha})$ at sowing plus foliar spray of $\mathrm{ZnSO}_{4} \cdot \mathrm{H}_{2} \mathrm{O}(0.3 \%) 30$ and 40 days after sowing; SEM - standard error of the mean; LSD - least significant difference; ${ }^{\text {a-e }}$ - means within columns with different superscripts are significantly different at $P \leq 0.05$

The CP content ranged from 8.13 to $9.76 \%$. The maximum mean increase in forage $\mathrm{CP}$ content was recorded in the $\mathrm{T}_{6}$ treatment which did not differ from the $\mathrm{T}_{4}$ and $\mathrm{T}_{5}$ treatments involving soil application of $16 \mathrm{~kg} / \mathrm{ha} \mathrm{ZnSO}_{4} \cdot \mathrm{H}_{2} \mathrm{O}$. The singular foliar application of $0.3 \% \mathrm{ZnSO}_{4} \cdot \mathrm{H}_{2} \mathrm{O} 30$ days after sowing $\left(\mathrm{T}_{2}\right)$ caused an increase in $\mathrm{CP}$ content in comparison to control treatment $(8.0 \%$ increase $)$. The CP content in fodder from the maize treated with double foliar application of $0.3 \% \mathrm{ZnSO}_{4} \cdot \mathrm{H}_{2} \mathrm{O} 30$ and 40 days after sowing $\left(\mathrm{T}_{3}\right)$ was higher than in the $\mathrm{T}_{2}$ treatment, but did not differ from the $\mathrm{T}_{4}$ and $\mathrm{T}_{5}$ treatments.

\section{Fibres estimation}

Neutral detergent and acid detergent fibres (NDF and $\mathrm{ADF}$, respectively) in the fodder decreased with $\mathrm{Zn}$ fertilization in the crop (Table 2). The highest decrease in NDF (5.4\%) and ADF (6.2\%) contents was recorded with treatment involving soil and two foliar applications of $\mathrm{ZnSO}_{4} \cdot \mathrm{H}_{2} \mathrm{O} 30$ and 40 days after sowing $\left(\mathrm{T}_{6}\right)$ over the control treatment. was found statistically on par with the $\mathrm{T}_{4}$ treatment. Double foliar application of $0.3 \% \mathrm{ZnSO}_{4} \cdot \mathrm{H}_{2} \mathrm{O}$ 30 and 40 days after sowing $\left(\mathrm{T}_{3}\right)$ caused a significantly higher TDN value $(63.1 \%)$ than the singular foliar spray $(62.7 \%)$. Similarly, the $\mathrm{T}_{5}$ treatment (soil plus singular foliar spray) also significantly improved the TDN value than the $\mathrm{T}_{2}$ treatment. However, statistically similar TDN values were recorded among $\mathrm{T}_{2}(62.7 \%), \mathrm{T}_{3}(63.1 \%)$ and $\mathrm{T}_{4}(63.0 \%)$ treatments, but all were significantly higher than the control $\left(\mathrm{T}_{1}\right)$. Zinc fertilization significantly reduced the forage hemi-cellulose (HC) content (Table 2). The $\mathrm{T}_{5}$ and $\mathrm{T}_{6}$ treatments recorded the lowest forage $\mathrm{HC}$ contents $(6.0 \%$ than the control).

Zinc fertilization significantly improved the forage DMI (Table 3). The soil treatment with $\mathrm{ZnSO}_{4} \cdot \mathrm{H}_{2} \mathrm{O}$ along with a double foliar spray of $\mathrm{ZnSO}_{4} \cdot \mathrm{H}_{2} \mathrm{O} 30$ and 40 days after sowing $\left(\mathrm{T}_{6}\right)$ or singular foliar spray of $\mathrm{ZnSO}_{4} \cdot \mathrm{H}_{2} \mathrm{O} 30$ days after sowing $\left(\mathrm{T}_{5}\right)$ caused the highest DMI (1.90 and $1.88 \%$ for $\mathrm{T}_{6}$ and $\mathrm{T}_{5}$, respectively) and that was 6.1 and 
$5.0 \%$ more than the control treatment, respectively. The foliar application of $0.3 \% \mathrm{ZnSO}_{4} \cdot \mathrm{H}_{2} \mathrm{O} 30$ days after sowing $\left(\mathrm{T}_{2}\right)$ and 30 and 40 days after sowing $\left(\mathrm{T}_{3}\right)$ caused statistically similar DMI means (1.82 and $1.83 \%$ ); however, both treatments were significantly higher than the control. Mean DMI under sole soil $\mathrm{ZnSO}_{4} \cdot \mathrm{H}_{2} \mathrm{O}\left(\mathrm{T}_{4}\right)$ fertilizer treatment was significantly higher than the foliar treatments $\left(\mathrm{T}_{2}\right.$ and $\left.\mathrm{T}_{3}\right)$. The forage DDM values were significantly improved with $\mathrm{ZnSO}_{4} \cdot \mathrm{H}_{2} \mathrm{O}$ fertilization, where the highest increase was stated with the $\mathrm{T}_{6}$ treatment which was statistically superior to all other treatments (Table 3). The mean increase in forage DDM of the $\mathrm{T}_{6}$ treatment over control reached $3.0 \%$.

Table 3. Effect of zinc (Zn) sulphate $\left(\mathrm{ZnSO}_{4} \cdot \mathrm{H}_{2} \mathrm{O}\right)$ application on dry matter intake (DMI), digestible dry matter (DDM) and digestible crude protein (DCM) of fodder maize (mean of two years)

\begin{tabular}{clll}
\hline Indices & DMI, \% DM basis & DDM, \% & DCP, \% \\
\hline Treatments & & & \\
$\mathrm{T}_{1}$ & $1.79 \pm 0.003^{\mathrm{d}}$ & $60.3 \pm 0.15^{\mathrm{e}}$ & $3.79 \pm 0.11^{\mathrm{c}}$ \\
$\mathrm{T}_{2}$ & $1.82 \pm 0.003^{\mathrm{c}}$ & $60.9 \pm 0.03^{\mathrm{d}}$ & $4.39 \pm 0.40^{\mathrm{bc}}$ \\
$\mathrm{T}_{3}$ & $1.83 \pm 0.007^{\mathrm{c}}$ & $61.3 \pm 0.07^{\mathrm{c}}$ & $4.61 \pm 0.28^{\mathrm{b}}$ \\
$\mathrm{T}_{4}$ & $1.86 \pm 0.003^{\mathrm{b}}$ & $61.3 \pm 0.20^{\mathrm{c}}$ & $4.81 \pm 0.28^{\mathrm{ab}}$ \\
$\mathrm{T}_{5}$ & $1.88 \pm 0.006^{\mathrm{a}}$ & $61.5 \pm 0.18^{\mathrm{b}}$ & $5.06 \pm 0.17^{\mathrm{ab}}$ \\
$\mathrm{T}_{6}$ & $1.90 \pm 0.006^{\mathrm{a}}$ & $62.1 \pm 0.09^{\mathrm{a}}$ & $5.30 \pm 0.02^{\mathrm{a}}$ \\
$\mathrm{SEM}$ & 0.01 & 0.11 & 0.21 \\
LSD & 0.016 & 0.35 & 0.67 \\
$(P \leq 0.05)$ & & & \\
\hline
\end{tabular}

${ }^{1}$ treatments: $\mathrm{T}_{1}=$ control, $\mathrm{T}_{2}=$ foliar spray of $\mathrm{ZnSO}_{4} \cdot \mathrm{H}_{2} \mathrm{O}(0.3 \%) 30$ days after sowing, $\mathrm{T}_{3}=$ two foliar sprays of $\mathrm{ZnSO}_{4} \cdot \mathrm{H}_{2} \mathrm{O}(0.3 \%) 30$ and 40 days after sowing, $\mathrm{T}_{4}=$ soil application of $16 \mathrm{~kg} / \mathrm{ha} \mathrm{ZnSO} \mathrm{Zn}_{4} \cdot \mathrm{H}_{2} \mathrm{O}$ at sowing, $\mathrm{T}_{5}=$ soil application of $\mathrm{ZnSO}_{4} \cdot \mathrm{H}_{2} \mathrm{O}(16 \mathrm{~kg} / \mathrm{ha})$ at sowing plus foliar spray of $\mathrm{ZnSO}_{4} \cdot \mathrm{H}_{2} \mathrm{O}(0.3 \%) 30$ days after sowing, and $\mathrm{T}_{6}=$ soil application of $\mathrm{ZnSO}_{4} \cdot \mathrm{H}_{2} \mathrm{O}(16 \mathrm{~kg} / \mathrm{ha})$ at sowing plus foliar spray of $\mathrm{ZnSO}_{4} \cdot \mathrm{H}_{2} \mathrm{O}(0.3 \%) 30$ and 40 days after sowing; SEM - standard error of the mean; LSD - least significant difference; $a-e$ - means within columns with different superscripts are significantly different at $P \leq 0.05$

Zinc fertilization to the soil, foliar or combination of both treatments significantly improved $\mathrm{NE}_{\mathrm{L}}$ of maize fodder (Table 4). The highest $\mathrm{NE}_{\mathrm{L}}$ value of $0.583 \mathrm{Mcal} / \mathrm{kg}$ was recorded for the $\mathrm{T}_{6}$ treatment which was statistically superior to all other treatments. The $\mathrm{T}_{3}, \mathrm{~T}_{4}$ and $\mathrm{T}_{5}$ treatments did not differ among each other but values in these treatments were significantly higher than in the $\mathrm{T}_{1}$ and $\mathrm{T}_{2}$ treatments. Significantly higher values of DFE of fodder were recorded in the $\mathrm{T}_{6}$ treatment involving soil and double foliar $\mathrm{ZnSO}_{4} \cdot \mathrm{H}_{2} \mathrm{O}$ fertilization approaches (Table 4). The $\mathrm{T}_{3}, \mathrm{~T}_{4}$ and $\mathrm{T}_{5}$ treatments recorded statistically similar values of DFE, but all were significantly higher than the control treatment.
Table 4. Effect of zinc $(\mathrm{Zn})$ sulphate $\left(\mathrm{ZnSO}_{4} \cdot \mathrm{H}_{2} \mathrm{O}\right)$ application on net energy for lactation $\left(\mathrm{NE}_{\mathrm{L}}\right)$, digestible feed energy (DFE), relative feed value (RFV) and relative forage quality (RFQ) of fodder maize (mean of two years)

\begin{tabular}{|c|c|c|c|c|}
\hline \multirow{2}{*}{ Indices } & NEL & DFE & RFV & RFQ \\
\hline & \multicolumn{2}{|l|}{ Mcal/kg } & \multicolumn{2}{|l|}{$\%$} \\
\hline \multicolumn{5}{|l|}{ Treatments $^{1}$} \\
\hline $\mathrm{T}_{1}$ & $0.521 \pm 0.005^{d}$ & $2.74 \pm 0.003^{d}$ & $84.1 \pm 0.34^{e}$ & $90.8 \pm 0.35^{f}$ \\
\hline $\mathrm{T}_{2}$ & $0.540 \pm 0.001^{c}$ & $2.76 \pm 0.003^{c}$ & $86.1 \pm 0.11^{d}$ & $92.9 \pm 0.12^{\mathrm{e}}$ \\
\hline $\mathrm{T}_{3}$ & $0.555 \pm 0.003^{b}$ & $2.78 \pm 0.003^{b}$ & $86.9 \pm 0.17^{d}$ & $93.7 \pm 0.17^{d}$ \\
\hline $\mathrm{T}_{4}$ & $0.553 \pm 0.007^{b}$ & $2.77 \pm 0.009^{b}$ & $88.3 \pm 0.42^{c}$ & $95.2 \pm 0.42^{c}$ \\
\hline $\mathrm{T}_{5}$ & $0.559 \pm 0.007^{b}$ & $2.78 \pm 0.006^{b}$ & $89.5 \pm 0.47^{b}$ & $96.5 \pm 0.47^{b}$ \\
\hline $\mathrm{T}_{6}$ & $0.583 \pm 0.002^{a}$ & $2.81 \pm 0.003^{a}$ & $91.5 \pm 0.10^{\mathrm{a}}$ & $98.5 \pm 0.15^{a}$ \\
\hline SEM & 0.004 & 0.005 & 0.26 & 0.28 \\
\hline $\begin{array}{l}\text { LSD } \\
(P \leq 0.05)\end{array}$ & 0.012 & 0.02 & 0.83 & 0.89 \\
\hline
\end{tabular}

${ }^{1}$ treatments: $\mathrm{T}_{1}=$ control, $\mathrm{T}_{2}=$ foliar spray of $\mathrm{ZnSO}_{4} \cdot \mathrm{H}_{2} \mathrm{O}(0.3 \%) 30$ days after sowing, $\mathrm{T}_{3}=$ two foliar sprays of $\mathrm{ZnSO}_{4} \cdot \mathrm{H}_{2} \mathrm{O}(0.3 \%) 30$ and 40 days after sowing, $\mathrm{T}_{4}=$ soil application of $16 \mathrm{~kg} / \mathrm{haZnSO} \mathrm{H}_{4} \cdot \mathrm{H}_{2} \mathrm{O}$ at sowing, $\mathrm{T}_{5}$ = soil application of $\mathrm{ZnSO}_{4} \cdot \mathrm{H}_{2} \mathrm{O}(16 \mathrm{~kg} / \mathrm{ha})$ at sowing plus foliar spray of $\mathrm{ZnSO}_{4} \cdot \mathrm{H}_{2} \mathrm{O}(0.3 \%) 30$ days after sowing, and $\mathrm{T}_{6}=$ soil application of $\mathrm{ZnSO}_{4} \cdot \mathrm{H}_{2} \mathrm{O}(16 \mathrm{~kg} / \mathrm{ha})$ at sowing plus foliar spray of $\mathrm{ZnSO}_{4} \cdot \mathrm{H}_{2} \mathrm{O}(0.3 \%) 30$ and 40 days after sowing; SEM - standard error of the mean; LSD - least significant difference; a-f - means within columns with different superscripts are significantly different at $P \leq 0.05$

\section{Relative feed value and relative forage quality}

A significant increase in RFV was observed with $\mathrm{Zn}$ fertilization of maize fodder (Table 4). Mean increase in RFV over the control was $9 \%$ under the $\mathrm{T}_{6}$ treatment. Foliar $\mathrm{ZnSO}_{4} \cdot \mathrm{H}_{2} \mathrm{O}$ treatments $\left(\mathrm{T}_{2}\right.$ and $\mathrm{T}_{3}$ ) recorded statistically similar mean RFV, but both treatments were significantly higher than the control one. Soil $\mathrm{ZnSO}_{4} \cdot \mathrm{H}_{2} \mathrm{O}$ application improved the RFV of fodder over foliar $\mathrm{ZnSO}_{4}$ treatments $\left(\mathrm{T}_{2}\right.$ and $\left.\mathrm{T}_{3}\right)$. The obtained results showed a higher RFQ index with various $\mathrm{Zn}$ fertilization treatments (Table 4). The highest RFQ value of 98.5 was recorded in the $\mathrm{T}_{6}$ treatment, which was significantly higher than in other treatments. Significantly lower RFQ value was recorded in foliar $\mathrm{ZnSO}_{4} \cdot \mathrm{H}_{2} \mathrm{O}$ fertilization $\left(\mathrm{T}_{2}\right.$ and $\left.\mathrm{T}_{3}\right)$ than soil $\mathrm{ZnSO}_{4} \cdot \mathrm{H}_{2} \mathrm{O}$ application, but all the treatments were significantly higher than the control treatment. The mean increases in RFQ under the $\mathrm{T}_{4}, \mathrm{~T}_{5}$ and $\mathrm{T}_{6}$ treatment reached 4.8, 6.3 and $8.5 \%$ respectively, over the control treatment. Foliar $\mathrm{ZnSO}_{4} \cdot \mathrm{H}_{2} \mathrm{O}$ treatment led to 2.3 to $3.1 \%$ improvement in mean RFQ over the control.

\section{Correlation analysis}

The correlation analysis of maize FFY, DMY, NDF, ADF, digestibility parameters and $\mathrm{ZnU}$ (Table 5) indicated significant $(P<0.05)$ or highly 


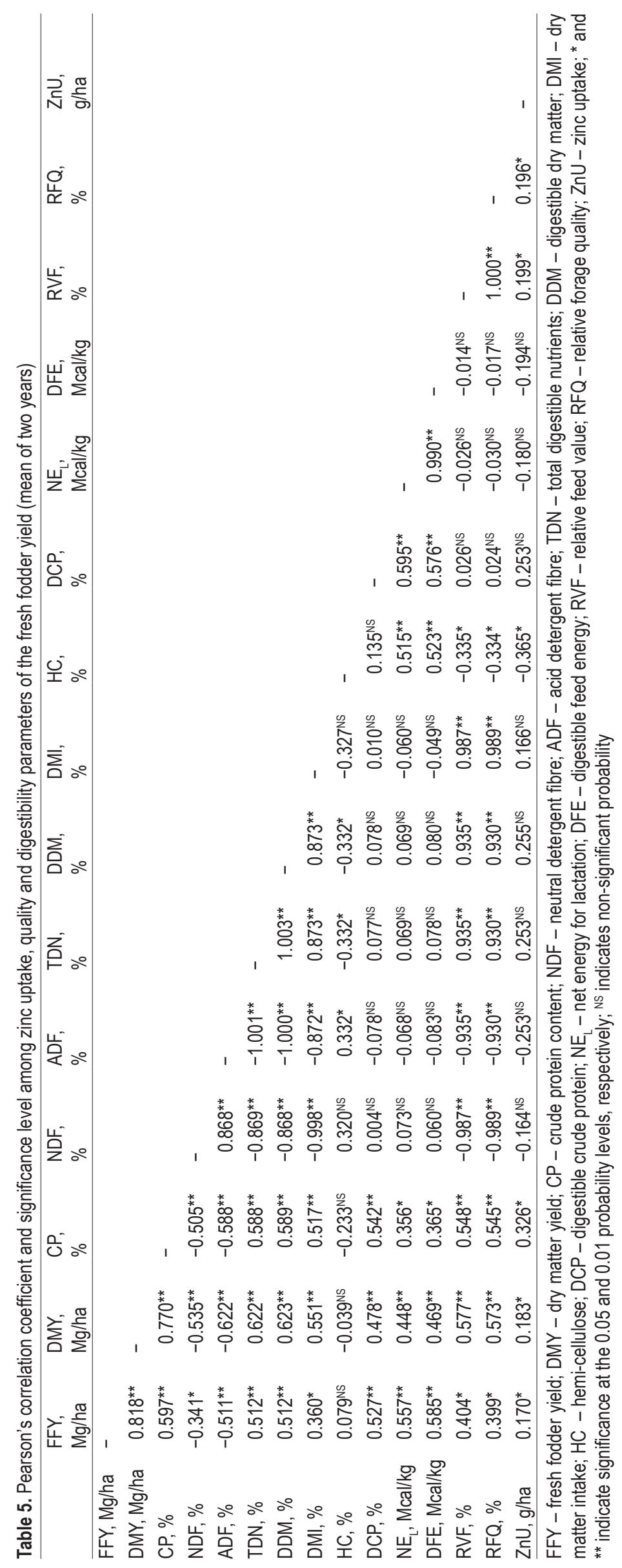


significant correlations $(P<0.01)$. The quality parameters such as $\mathrm{CP}, \mathrm{TDN}, \mathrm{DDM}$ and DMI were significantly and positively correlated with FFY and DMY. Zinc fertilization significantly reduced $\mathrm{HC}$ content of fodder as a significant negative correlation (Table 5) existed between $\mathrm{ZnU}$ and $\mathrm{HC}$ content $\left(-0.365^{*}\right)$, however, NDF and ADF content tended to be negatively correlated (not significantly) with $\mathrm{ZnU}$. Positive $(P<0.01)$ correlations were recorded between FFY and DCP $\left(0.527^{* *}\right)$; FFY and $\mathrm{NE}_{\mathrm{L}}\left(0.583^{* *}\right)$ as well as FFY and DFE $\left(0.585^{* *}\right)$ of fodder. Finally, $\mathrm{Zn}$ fertilization through soil, foliar and combination of both improved quality of fodder, as positive correlations were recorded with respect to ZnU-RFV index (0.199*) and ZnU-RFQ index $\left(0.196^{*}\right)$. A positive correlations $(P<0.01)$ also existed between $\mathrm{ZnU}$ and FFY $\left(0.170^{*}\right)$, and $\mathrm{ZnU}$ and $\operatorname{DMY}\left(0.183^{*}\right)$. However, no correlation was recorded between $\mathrm{ZnU}$ and other digestibility parameters such as TDN, DDM, DMI, DCP, $\mathrm{NE}_{\mathrm{L}}$ and DFE.

\section{Discussion}

In the present study, the increase in FFY and DMY with $\mathrm{Zn}$ application was attributed to better plant growth and development under $\mathrm{Zn}$ application treatments. The positive effects of $\mathrm{Zn}$ fertilization either through soil or foliar application on the yield of cereals and legumes such as wheat, rice, soyabean, chickpea and cowpea grain had also been reported by several other researchers (Alloway, 2008; Cakmak and Kutman, 2018; Pal et al., 2020; Kumar and Dhaliwal, 2021). However, information on the biofortification of maize fodder with Zn and its impact on green fodder yield and its quality attributes are scarce. Zinc is known to activate various enzymatic reactions and improve photosynthesis and improve carbohydrate assimilate portioning from source to sink which led to an increase in FFY and DMY. Zinc application to soil alone was superior to one and two foliar applications in enhancing the FFY and DMY which might be due to more and longer availability of $\mathrm{Zn}$ to the crop. During early growth stages, adequate soil available $\mathrm{Zn}$ is important to get high fodder yield as a foliar application of $\mathrm{Zn}$ at late growth stage recorded less FFY and DMY than soil $\mathrm{Zn}$ application method (Kumar and Dhaliwal, 2021). Plants with $\mathrm{Zn}$ deficiency in the early stages of development find it difficult to express their maximum genetic potential which might be due to damage both in the maintenance of enzyme activity as well as enzyme synthetase of tryptophan (Castagnara et al., 2012).
Minerals and trace elements derived from forages play an important role in milk production, reproduction and maintaining livestock health (Kumar et al., 2016; Ali et al., 2019). For better growth and development of cattle, proper supply of trace elements such as $\mathrm{Zn}$ through good quality fodder is important. Plant research has focused on the goal of biofortifying cereals, mainly rice and wheat, but there is still potential to improve the nutritional quality of forage crops (Capstaff and Miller, 2018). Different $\mathrm{Zn}$ fertilization methods significantly improved $\mathrm{ZnU}$ in the fodder which might be due to its role in photosynthesis and metabolic processes, which help in augmenting the production of photosynthates and their translocation to different parts, finally increasing $\mathrm{ZnU}$ by the forage crop (Pal et al., 2020; Kumar and Dhaliwal, 2021). Higher Zn availability to cattle through $\mathrm{Zn}$ enriched fodder will meet the requirement of $\mathrm{Zn}$ which is very important for the immune system in the livestock (Capstaff and Miller, 2018). Zinc applications through the soil and a combination of soil and foliar treatments were more effective in increasing $\mathrm{ZnU}$ than the foliar treatment alone. This may be due to the early continuous supply of $\mathrm{Zn}$ to the crop, in addition, later foliar applications also loaded more $\mathrm{Zn}$ in leaves resulting in higher yield and $\mathrm{ZnU}$ in plants. Yerokun and Chirwa (2014) reported that soil application of $\mathrm{Zn}$ was more effective in raising yield level, whereas, foliar application of 2-4 kg Zn per ha was most effective for increasing the $\mathrm{Zn}$ mass concentration in plant tissues of maize. In the foliar application of $\mathrm{Zn}\left(\mathrm{T}_{2}\right.$ and $\left.\mathrm{T}_{3}\right)$, an increase in $\mathrm{ZnU}$ occurred due to the easy penetration of $\mathrm{Zn}$ into the plant through stomatal pores as reported by Gupta et al. (2016), but both soil and foliar applications of $\mathrm{Zn}$ fertilizers enhance plant-available $\mathrm{Zn}$ pool. Considering the daily dietary requirement of $30 \mathrm{mg} / \mathrm{kg} \mathrm{DM}$ for adult cattle, the increased $\mathrm{ZnU}$ upon $\mathrm{Zn}$ fertilization will meet the requirements of livestock, particularly, in South Asian countries where soils and forage crops are generally deficient in Zn (Ryan et al., 2013; Kumar et al., 2016). Hosnedlova et al. (2007) reported that $\mathrm{Zn}$ content in cattle milk can be influenced by forage nutrition. Feeding maize fodder enriched with $\mathrm{Zn}$ to the livestock will increase milk production, improve reproduction efficiency and will reduce the susceptibility to infectious diseases such as metritis and mastitis which will further boost the dairy industry as a whole (Hosnedlova et al., 2007; Alloway, 2008; Gupta et al., 2016; Kumar et al., 2016).

Zinc fertilization reduced NDF, ADF and $\mathrm{HC}$ contents in the fodder, which could be attributed to 
the fact that higher $\mathrm{Zn}$ availability promoted protein synthesis and decreased the soluble carbohydrate content in the fodder resulting in higher palatability and digestibility (Alloway, 2008; Capstaff and Miller, 2018). Castagnara et al. (2012) also reported significantly lower values of fibres (NDF and ADF) at doses of 0.2 and $0.4 \mathrm{mg} / \mathrm{dm}^{3}$ of $\mathrm{Zn}$, respectively in the white oats (Avena sativa L.) grown in soil with moderate $\mathrm{Zn}$ content in the glasshouse. Considerable reduction in the fibre values and enhancement of protein content of fodder with soil and foliar $\mathrm{Zn}$ fertilization, in this study, indicated more intake and digestibility of the fodder.

For livestock producers, obtaining high forage yield along with high-quality for animals is the prime objective. Improvement in estimated digestibility parameters such as TDN, DMI, DDM and DCP with soil, foliar and soil plus foliar $\mathrm{ZnSO}_{4}$ application reflected that, under $\mathrm{Zn}$ deficient soil, $\mathrm{Zn}$ fertilization through soil plus foliar application could be one of the most important criteria for increasing the yield and quality of maize fodder. Total digestible nutrients are a measure of forage energy as well as forage digestibility, the values of which were significantly increased with different $\mathrm{Zn}$ fertilization methods. Typically, the greater the value of TDN, the more energy-dense feedstuff is considered (Kumar et al., 2016). Good quality fodder must contain TDN equal or greater than $65 \%$ (Ali et al., 2019). However, observed TDN in the present study among different $\mathrm{ZnSO}_{4}$ treatments ranged from 62.7 to 63.7 (mean value), although was significantly higher in treatment $\mathrm{T}_{6}$, which falls within the range of good quality forage as reported above. Digestible dry matter is the percentage of a forage sample that is digestible (Kumar et al., 2016). Zinc application to the crop increased the DDM as it improved the fodder quality by reducing fibres. Dry matter intake is the amount of DM consumed by the animal and intake increases as the digestibility of forage increases (Kumar et al., 2016; Lithourgidis et al., 2006). The reduction in HC percentage in fodder with $\mathrm{Zn}$ fertilization improved the DDM and DMI of the fodder. The improved DMI of fodder with $\mathrm{Zn}$ fertilization is an indication of better performance of the livestock in terms of milk and meat production. Rana et al. (2013) also recorded significantly higher in vitro DMD (IVDMD) and DDM in sorghum with foliar sprays of $0.5 \% \mathrm{ZnSO}_{4} 35$ and 45 days after sowing over control. The increased $\mathrm{ZnU}$ due to various $\mathrm{Zn}$ fertilization treatments recorded a significant and positive correlation with $\mathrm{CP}\left(0.326^{*}\right)$ and TDN percent $\left(0.250^{*}\right)$ indicating that $\mathrm{Zn}$ application improved these parameters which are essential for livestock health and development.

Relative feed value is an index used to rank the forages according to their overall nutritive value. Relative feed value and RFQ are good indicators for the forage digestibility and quality, in addition to CP content (Lithourgidis et al., 2006; Kumar et al., 2016). Zinc application either through the soil, foliar spraying or combination of both improved RFV and RFQ of fodder over the control treatment, ensuring a better quality of the forage for livestock. Soil application of $16 \mathrm{~kg} \mathrm{ZnSO} \cdot \mathrm{H}_{2} \mathrm{O}$ per ha plus foliar sprays with $0.3 \% \mathrm{ZnSO}_{4} \cdot \mathrm{H}_{2} \mathrm{O}$ resulted in the higher RVF and RFQ over control, possibly due to sustained and longer availability of $\mathrm{Zn}$ through soil and foliar application which might have helped in better digestibility and DMI of fodder. The higher RFQ, the higher will be the quality of fodder and the better will be the performance of cattle. Lower RVF and RFQ values were reported with foliar $\mathrm{ZnSO}_{4}$ treatments than with soil $\mathrm{Zn}$ application, indicating that $\mathrm{Zn}$ is essential for maize at early growth stages for getting better quality fodder for livestock. This was confirmed in this study as a positive correlations between ZnU-RFV and ZnU-RFQ of fodder were recorded. Similarly, Sajad et al. (2014) observed the highest RFV of maize fodder (79.3\%) in treatment involving $100 \mathrm{~kg} \mathrm{~N} / \mathrm{ha}+10 \mathrm{~kg} \mathrm{Zn} / \mathrm{ha}$ than in the control (78.1\%).

The present investigation confirmed that fodder maize performed well and produced higher FFY, with better quality in terms of better TDN, DDM, DMI, $\mathrm{CP}, \mathrm{NE}_{\mathrm{L}}$, DCP, RFV and RFQ under $\mathrm{ZnSO}_{4} \cdot \mathrm{H}_{2} \mathrm{O}$ fertilization treatments, probably because of the better conversion of assimilates in plants. This was confirmed by the correlation study which showed a positive significant association between the FFY, DMY and fodder quality and digestibility parameters. Nonetheless, Zn fertilization significantly reduced the NDF, ADF and HC content of fodder which was clearly indicated with the negative correlations between $\mathrm{Zn}$ and fibres (ZnU-HC; ZnU-NDF and ZnU-ADF), thereby indicating higher digestibility and DMI of fodder by the livestock. Good quality forage has less crude fibre, higher digestibility and DMI (Lithourgidis et al., 2006; Kumar et al., 2016).

\section{Conclusions}

In the current study, the application of $\mathrm{ZnSO}_{4} \cdot \mathrm{H}_{2} \mathrm{O}$ resulted in a significant increase in fresh fodder yield (FFY), dry matter yield (DMY), quality and estimated digestibility parameters of 
fodder maize. Zinc application improved crude protein (CP) content, total digestible nutrients (TDN), dry matter digestibility (DDM) and dry matter intake (DMI) of the fodder. Fodder quality improvement, in terms of reduction in fibre contents (neutral detergent fibre (NDF), acid detergent fibre (ADF) and hemicellulose (HC) and enhancement in relative feed value (RFV) and relative forage quality (RFQ) was obtained with soil and foliar $\mathrm{ZnSO}_{4}$ fertilizer application. The increase in FFY, CP content and higher $\mathrm{Zn}$ accumulation due to $\mathrm{Zn}$ application will improve the economic status of livestock producers. Soil application of $16 \mathrm{~kg} \mathrm{ZnSO}_{4} \cdot \mathrm{H}_{2} \mathrm{O}$ per ha at sowing plus foliar applications of $0.3 \%$ solution of $\mathrm{ZnSO}_{4} \cdot \mathrm{H}_{2} \mathrm{O} 30$ and 40 days after sowing was the best treatment in terms of improving yield and quality of maize fodder. This treatment can be recommended to grow maize fodder on soils with low-available $\mathrm{Zn}$ content and to obtain a high forage productivity with improved quality.

\section{Conflict of interest}

The authors declare that there is no conflict of interest.

\section{References}

Ahmad W., Watts M.J., Imtiaz M., Ahmed I., Zia M.H., 2012. Zinc deficiency in soils, crops and humans: a review. Agrochimica $56,65-97$

AOAC International, 2000. Official Methods of Analysis of AOAC International. $17^{\text {th }}$ Edition. Gaithersburg, MD (USA)

Ali W., Nadeem M., Ashiq W., Zaeem M., Thomas R., Kavanagh V., Cheema M., 2019. Forage yield and quality indices of silagecorn following organic and inorganic phosphorus amendments in Podzol soil under Boreal climate. Agronomy 9, 489, https:// doi.org/10.3390/agronomy9090489

Alloway B.J., 2008. Zinc in Soils and Crop Nutrition (2 ${ }^{\text {nd }}$ Edition). International Zinc Association (IZA), Brussels (Belgium); and International Fertilizer Industry Association (IFA), Paris (France)

Anees M.A., Ali A., Shakoor U., Ahmed F., Hasnain Z., Hussain A., 2016. Foliar applied potassium and zinc enhances growth and yield performance of maize under rainfed conditions. Int. J. Agric. Biol. 18, 1025-1032, https://doi.org/10.17957//JAB/15.0204

Bhatti D.S., Kaur S., 2020. Package of Practices for the Crops of Punjab (Kharif 2020). 37, Punjab Agricultural University, Ludhiana (India), pp. 72-73

Cakmak I., Kutman U.B., 2018. Agronomic biofortification of cereals with zinc: a review. Eur. J. Soil Sci. 69, 172-180, https://doi. org/10.1111/ejss.12437

Capstaff N.M., Miller A.J., 2018. Improving the yield and nutritional quality of forage crops. Front. Plant Sci. 9, 535, https://doi. org/10.3389/fpls.2018.00535

Castagnara D.D., Krutzmann A., Zoz T., Steiner F., Conte e Castro A.M., Neres M.A., Rabello de Oliveira P.S., 2012. Effect of boron and zinc fertilization on white oats grown in soil with average content of these nutrients. R. Bras. Zootec. 41, 1598-1607, https://doi.org/10.1590/S1516-35982012000700007
Gupta N., Ram H., Kumar B., 2016. Mechanism of zinc absorption in plants: uptake, transport, translocation and accumulation. Rev. Environ. Sci. Bio. 15, 89-109, https://doi.org/10.1007/ s11157-016-9390-1

Hosnedlova B., Travnicek J., Soch M., 2007. Current view of the significance of zinc for ruminants: a review. Agric. Trop. Subtrop. 40, 57-64

IRRI (International Rice Research Institute), 1992. IRRISTAT User's Manual version 92-1. IRRI, Los Baños (Philippines)

Jackson M.L., 1973. Soil Chemical Analysis. Prentice Hall of India Pvt. Ltd. New Delhi (India)

Kumar B., Brar N.S., Verma H.K., Kumar A., Singh R., 2019. Nutritious feed for farm animals during lean period: silage and hay a review. Forage Res. $45,10-22$

Kumar B., Dhaliwal S.S., 2021. Zinc biofortification of dual-purpose cowpea [Vigna unguiculata (L.) Walp.] for enhancing the productivity and nutritional quality in a semi-arid regions of India. Arch. Agron. Soil Sci. 67, 1-15, https://doi.org/10.1080/ 03650340.2020.1868040

Kumar B., Dhaliwal S.S., Singh S.T., Lamba J.S., Ram H., 2016. Herbage production, nutritional composition and quality of teosinte under Fe fertilization. Int. J. Agric. Biol. 18, 319-329, https://doi.org/10.17957/IJAB/15.0089

Lithourgidis A.S., Vasilakoglou I.B., Dhima K.V., Dordas C.A., Yiakoulaki M.D., 2006. Forage yield and quality of common vetch mixtures with oat and triticale in two seeding ratios. Field Crops Res. 99, 106-113, https://doi.org/10.1016/j. fcr.2006.03.008

Page A.L., Miller R.H., Keeney D.R. (Editors), 1982. Methods of Soil Analysis. Part 2. Chemical and Microbiological Properties. $2^{\text {nd }}$ Edition. American Society of Agronomy (ASA) and Soil Science Society of America. Madison, WI (USA)

Pal V., Singh G., Dhaliwal S.S., 2020. Symbiotic parameters, growth, productivity and profitability of chickpea as influenced by zinc sulphate and urea application. J. Soil Sci. Plant Nutr. 20, 738-750, https://doi.org/10.1007/s42729-019-00161-5

Rana D.S., Singh B., Gupta K., Dhaka A.K., Arya S., 2013. Response of fodder sorghum [Sorghum bicolor (L.) Moench] to zinc and iron. Forage Res. 39, 45-47

Ryan J., Rashid A., Torrent J., Yau S.K., Ibrikci H., Sommer R., Erenoglu E.B., 2013. Micronutrient constraints to crop production in the Middle East-West Asia region: significance, research and management. Adv. Agron. 122, https://doi.org/10.1016/B978-012-417187-9.00001-2

Sajad A., Jamil M., Ahmad M., Abbasi G.H., Fakhar-u-Zaman M., 2014. An investigation on nitrogen-zinc interaction synergise maize (Zea mays L.) fodder quality. World Appl. Sci. J. 31, 91-95, https://www.idosi.org/wasj/wasj31(1)14/12.pdf

Tripathi S.B., Rai A.K., Dixit A.K., Singh K.A., 2009. Improving yield and quality of fodders through secondary and micronutrients. Indian J. Fert. 5, 81-96

Van Soest P.J., Robertson J.B., Lewis B.A., 1991. Methods for dietary fiber, neutral detergent fiber, and non starch polysaccharides in relation to animal nutrition. J. Dairy Sci. 74, 3583-3597, https://doi.org/10.3168/jds.S0022-0302(91)78551-2

Wadhwa M., Kaur K., Kumar B., Bakshi M.P.S., 2010. Comparative evaluation of non leguminous forages as livestock feed. Indian J. Anim. Nutr. 27, 44-49

Yadav S., Khirwar S.S., 2000. Soil-plant-animal relationship of zinc in milch buffaloes of Jind district in Haryana. Indian J. Anim. Sci. 70, 965-967

Yerokun O.A., Chirwa M., 2014. Soil and foliar application of zinc to maize and wheat grown on a Zambian Alfisol. Afr. J. Agric. Res. 9, 963-970, https://doi.org/10.5897/AJAR2013.7623 